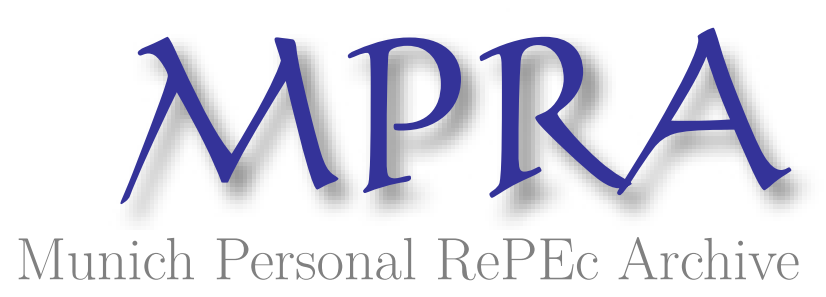

\title{
United Arab Emirates FDI Outlook
}

\author{
Mina, Wasseem \\ United Arab Emirates University, Economic Research Forum
}

29 November 2013

Online at https://mpra.ub.uni-muenchen.de/51810/

MPRA Paper No. 51810, posted 30 Nov 2013 23:46 UTC 


\title{
United Arab Emirates FDI Outlook
}

\author{
Wasseem Mina ${ }^{1}$
}

\begin{abstract}
:
FDI is important in building a sustainable and diversified knowledge-based UAE economy. The stock of FDI grew at an average annual growth rate of 45.3 percent over the past decade reaching US\$ 95 billion or nearly 27 percent of GDP in 2012. FDI flows have not recovered from the global financial crises. Most FDI stock is concentrated in finance, construction, and real estate. Recent greenfield FDI is concentrated in construction, while more than half of top M\&A deals took place in finance, transportation, communications and utilities. The list of top OECD home countries for FDI flows to the UAE include Italy, Germany, Chile, United Kingdom, Luxembourg, France, United States, and Belgium. Though UAE investment policy limits foreign investment and reduces competition, the Government has undertaken reforms and contracted investment treaties that have encouraged investment. Efforts are under way to speed up the ratification of a new foreign investment law, which removes several of the current legal barriers to FDI and offers foreign investors similar rights to those of UAE nationals. The UAE has high FDI potential with plenty of room for improving FDI performance and benefiting the economy.

Keywords: FDI; Outlook; UAE

JEL classification: F21; F23
\end{abstract}

\footnotetext{
${ }^{1}$ Department of Economics and Finance, College of Business and Economics, United Arab Emirates University, P.O. Box 15551, Al Ain, UAE. (email: wmina@uaeu.ac.ae), and Economic Research Forum. This outlook builds on an earlier work by the author (Wasseem Mina, "Inward FDI in the United Arab Emirates and its policy context," Columbia FDI Profiles, (ISSN: 21592268), December 21, 2012; and Wasseem Mina, "Inward FDI in the United Arab Emirates and its Policy Context." In Inward and Outward FDI Country Profiles, eds. Karl P. Sauvant, Padma Mallampally and Geraldine McAllister. New York: Vale Columbia Center on Sustainable International Investment (ISSN: 2159-2268), second edition 2013). The author would like to thank the Vale Columbia Center on Sustainable International Investment's Karl Sauvant, Padma Mallampally, Geraldine McAllister, and Ana-Maria Poveda-Garces for their excellent comments and tremendous support with earlier versions, Raimundo Soto, Jay Squalli, and Fernando Zanella for peer-review comments, Mohammed Zaheeruddin (UAEU College of Law) for clarification of legal points in UAE law, participants at the UAEU College of Business and Economics' Economic and Finance Research seminar series and Abdalla Al Muaini (UAEU DBA Program) for helpful comments. The usual disclaimer applies.
} 


\section{United Arab Emirates FDI Outlook}

\section{INTRODUCTION}

The purpose of this article is to provide an FDI outlook for the United Arab Emirates (UAE) and discuss the policy environment in which FDI has nourished. The outlook provides FDI information that covers the aggregate, sectorial and corporate levels, and highlights policy developments surrounding UAE FDI performance and the extent to which FDI has benefitted the economy.

UAE is one of six Gulf Cooperation Council (GCC) countries, which comprise Bahrain, Kuwait, Oman, Qatar, Saudi Arabia, and the UAE. It is also one of the four GCC OPEC members, which include Kuwait, Qatar, Saudi Arabia, and the UAE. ${ }^{2}$

FDI is considered an important factor in UAE efforts to reduce reliance on natural resources and diversify its economy in the long term. The UAE government aims to build a sustainable knowledge based economy, as projected in the UAE 2021 Vision. The UAE 2021 Vision charts the goals and steps for the next stage of the nation's progress leading up to the year 2021. Theme 3 of the Vision, "United in Knowledge", emphasizes that, in creating a sustainable and diversified economy, home-grown entrepreneurship is to be stimulated and FDI to be attracted. Accordingly, FDI is envisaged as one of the pillars for the structural transformation of the economy.

The UAE has a high inward FDI potential as reflected in the high UNCTAD's Inward FDI Potential Index ranking. In 2008 and 2009, UAE's inward FDI potential index was ranked third and fifth among 142 countries, respectively (Table 1). In 2011, the index was ranked $19^{\text {th }}$ among 177 economies with high potential on market attractiveness (ranked ninth), enabling infrastructure (ranked $28^{\text {th }}$ ) and presence of natural resources (ranked $45^{\text {th }}$ ) (Table 2). ${ }^{3}$ With such potential, the UAE aspires to becoming a global investment hub, which also helps the Government to fulfill its vision for diversifying the economy.

\footnotetext{
${ }^{2}$ The UAE is composed of seven emirates: Abu Dhabi, Dubai, Sharjah, Ajman, Umm Al Quwain, Fujairah, and Ras Al Khaimah.

${ }^{3}$ Qatar, Kuwait, and Saudi Arabia have higher rank on market attractiveness, while Saudi Arabia has higher rank on natural resources.
} 


\section{[Insert Table 1 here.]}

\section{[Insert Table 2 here.]}

With such potential, FDI can be beneficial to the UAE economy in the long run. Studies, such as Alfaro et al. (2009), Blomström and Kokko (1998), Borensztein et al. (1998), UNCTAD (1999), and Cipollina et al. (2012), have shown that FDI has its benefits. Under appropriate conditions - mainly availability of human capital and developed financial system - FDI can boost capital formation, employment, exports economic growth, and protection of the environment in host economies. It also results in technology transfer and productivity spillovers to local firms through forward and backward linkages, local firms imitating MNEs, or hiring workers trained by MNEs. ${ }^{4}$ Technology, which includes product, process and distribution technologies, in addition to management and marketing skills, can be important for the diversification of the UAE economy, and its transformation to a knowledge-based economy. Some preliminary evidence on the benefits of FDI to the UAE economy is provided in the last section of the outlook.

\section{FDI: LEVEL AND DISTRIBUTION}

UAE FDI stock grew from US\$ 1 billion (1 percent of GDP) in 2000 to US\$ 95 billion (26.9 percent of GDP) in 2012, the second highest GCC country after Saudi Arabia. The average annual growth rate of FDI stock (45.3 percent) is the highest in the GCC region (Table 3).

\section{[Insert Table 3 here.]}

The take-off point for UAE's FDI was 2003, when the FDI stock rose to US\$ 7 billion (5.3 percent of GDP). From 2004 to 2012, UAE's FDI stock exceeded the total stock of Bahrain, Kuwait, Oman, and Qatar taken together, reflecting the competitiveness and attractiveness of the UAE as an investment destination not only within the GCC but

\footnotetext{
${ }^{4}$ Cipollina et al. (2012), for example, find positive effects of FDI on the rate of growth of industries in host countries. The rate of growth increases in capital-intensive and technologically developed sectors.
} 
also within the wider Middle East and North Africa region, as discussed in the policy scene section below.

FDI flows to the UAE grew from US\$ 1.2 billion (1.1 percent of GDP) in 2001, to a peak of US\$ 14.2 billion (5.5 percent of GDP) in 2007. FDI flows dropped significantly following the financial crisis to US\$ 4 billion (1.5 percent of GDP) in 2009. Flows rose gradually in 2010-2012, but still remained in 2012 well below the peak of 2007 at US\$ 9.6 billion (2.7 percent of GDP). Compared to FDI flows to other GCC countries, FDI flows to the UAE in 2011 and 2012 exceeded total flows of Bahrain, Kuwait, Oman and Qatar.

Sectorial distribution of FDI during the second half of the 2000s reveals that nearly two thirds of the FDI stock is concentrated in finance, construction, and real estate. WTO's 2012 Trade Policy Review of the UAE provides data on the sectorial distribution of FDI for the period 2005-2009 (Table 4). ${ }^{5}$ During the period, financial institutions, construction, and real estate amounted on average for 23 percent, 21 percent, and 21 percent, respectively, of the FDI stock. ${ }^{6}$ While the shares of financial institutions and construction remained largely stable, the share of real estate in the stock of FDI was the most volatile among the different sectors as the global financial crisis has revealed. The crisis has led to a collapse of the real estate bubble and reduced real estate FDI: The share of real estate in the stock of FDI declined by 11 percentage points from 28 percent to 17 percent between 2008 and 2009.

\section{[Insert Table 4 here.]}

Although the geographical distribution of FDI flows by home countries is not published in the $\mathrm{UAE}^{7}$ data on OECD countries' outward FDI flows to the UAE since

\footnotetext{
${ }^{5}$ WTO (2012) states the UAE government is working on the improvement of FDI statistics collection, particularly by source (page 12).

${ }^{6}$ Linking sectorial distribution of FDI to economic growth, Cipollina et al. (2012) cite studies which find positive effect of FDI on growth using sector level data: Caves (1974) for Australia, Globerman (1979) for Canada, Blömstrom and Persson (1983), Blömstrom and Wolff (1994) for Mexico, Sjöholm (1999) for Indonesia, Haskel et al. (2006) for UK, and Keller and Yeaple (2009) for US.

${ }^{7}$ FDI data collection and dissemination need to be improved in the MENA and GCC countries. In the past, there were discussions on FDI-related technical assistance spearheaded by the IMF.
} 
2003, the FDI take-off year, show that the home countries with total period flows of US $\$ 0.5$ billion or above were Italy (US $\$ 2.2$ billion), Germany (US $\$ 1.7$ billion), Chile (US $\$ 1.3$ billion), United Kingdom (US\$1.2 billion), Luxembourg (US\$1 billion), France (US $\$ 1$ billion), United States (US $\$ 0.9$ billion), and Belgium (US $\$ 0.5$ billion) (Table 5). With the onset of the global financial crisis in 2008, FDI flows from Luxembourg, Switzerland, and France interestingly recorded historical figures, amounting to US\$18.5 billion, US $\$ 7.4$ billion, and US $\$ 1.2$ billion, respectively. In addition to OECD countries, FDI flows to UAE originated from GCC economies, China, India, and Malaysia according to the information on cross-border M\&As and greenfield FDI projects, as discussed in the next section. ${ }^{8}$

\section{[Insert Table 5 here.]}

\section{FDI MODE AND CORPORATE PLAYERS}

According to UNCTAD, the number of greenfield FDI projects more than doubled since the inward FDI take-off in 2003: The number of projects more than doubled from 150 in 2003 to 328 in 2012 with value increasing from US\$ 9 billion to US\$ 12 billion (Table 6). Detailed corporate-level data available on the largest announced greenfield FDI projects for 2008-2010 suggest that they were highly concentrated in construction (Table 7). ${ }^{9}$ The total value of the largest greenfield investments announced by inward-investing firms in the construction industry amounted to nearly US\$ 20 billion. As table 7 also shows the largest greenfield investments announced also included projects in transportation, communications and utilities, and manufacturing, and amounted to more than US $\$ 4$ billion. ${ }^{10}$ Of the nearly 40 main greenfield investments announced, eight originated from the United States and six from the United Kingdom.

The IMF Middle East Regional Technical Assistance Centre's (METAC) 2009 Programme document sheds light on FD technical assistance for the region as a whole.

${ }^{8}$ According to Satyanand and Raghavendran (2010), India's FDI outflows to the UAE amounted to US\$ 2.2 billion in 2002-2009.

${ }^{9}$ This perhaps explains why the UAE Government undertook business reforms making it easier to obtain construction permits, as mentioned below in the discussion of the policy scene.

${ }^{10}$ Economic growth has also been examined using firm and plant level data. A number of studies have looked into positive spillover effects of foreign firms using firm and plant level data 


\section{[Insert Table 6 here.]}

\section{[Insert Table 7 here.]}

The number of cross-border M\&As by inward-investing firms numbered 7 in 2003 and 28 in 2012. Detailed corporate-level data on the largest M\&As by inward investing firms for the period 2008-2010 show that more than half the M\&A deals took place in the services sector, in particular in finance as well as in transportation, communications and utilities (Table 8). Out of 38 top M\&A deals, six originated from the United States, seven from the United Kingdom, nine from other GCC countries (Kuwait, Qatar, and Saudi Arabia), three from India, and two from Malaysia.

\section{[Insert Table 8 here.]}

Many foreign MNEs operating in the UAE include U.S. Fortune 500 companies, both financial and non-financial (Table 9). The total number of U.S. MNEs' affiliates in the UAE with assets, sales or net income greater than US\$ 25 million amounted to 113 in 2010, according to U.S. Bureau of Economic Analysis data, and 95 of them were majority-owned affiliates. Those majority-owned affiliates employed about 19,500 employees, of whom 4,400 were in professional, scientific and technical services, 4,300 in manufacturing, 1,900 in wholesale, and 1,900 in mining. The total compensation paid to employees of the majority-owned affiliates was US\$1.2 billion, and the value-added generated by those affiliates amounted to US\$ 5.9 billion, of which about US\$ 4.1 billion was generated in the mining industry alone.

\section{[Insert Table 9 here.]}

\section{THE POLICY SCENE}

According to the WTO's 2006 and 2012 Trade Policy Reviews of the UAE, UAE's investment policy limits foreign investment, except in the free zones where 100 percent foreign ownership is allowed, and thus reduces competition between local and

(Cipollina et al. 2012). Some studies have found no spillovers (Aitken and Harrison 1999) and weak evidence of positive horizontal externalities (Alfaro and Rodriguez-Clare 2004), while other firm- and plant-level studies have found strong evidence of knowledge spillovers (Branstetter 2006; Haskel et al. 2006; and Keller and Yeaple 2009). 
foreign investors in the economy. The Federal Commercial Companies Law (No. 8 of 1984) and its amendments stipulate that UAE nationals must hold at least 51 percent of the capital of any company established in the UAE. However, there are exceptions to this provision for a) other GCC countries' nationals, who are granted national treatment and may have up to 100 percent ownership in most activities, and for b) companies registered as branches or representative offices of foreign companies established in Dubai.

The UAE Government has established nearly 40 free zones, in which 100 percent foreign ownership is allowed and no taxes are levied. The highest concentration of the free zones is in Dubai, with more than half of the total number of free zones (23), followed by Abu Dhabi (5), Ras Al Khaimah (4), Fujeirah (3), Sharjah (2), Ajman (1), and Umm Al Quwain (1). ${ }^{11}$ Outside the free zones, local sponsors are needed for foreign companies to be established, and foreign ownership is limited to a maximum of 49 percent.

According to United States Government Accountability Office (2008) report, in addition to the Federal Commercial Companies Law and its amendments (company law), the Commercial Agencies Law (Federal Law No. 13 of 2006 on Deregistration of Trade Agencies) represents another legal barrier to FDI in the UAE, as it stipulates that the operations of foreign importers need to be done through a sole UAE agent, either a national or a fully national-owned company, and the terms of the agency relationship. However, changes were introduced in 2009 with modifications to make contracts more easily enforceable. Modifications, for example, limited the agency contract to a fixed

\footnotetext{
${ }^{11}$ Dubai's 23 free zones are Jebel Ali Free Zone, Dubai Techno Park, Dubai Auto Zone, Dubai Gold \& Diamond Park, Dubai Logistics City, Dubai Aviation City, Dubai Knowledge Village, Dubai Media City, Dubai Studio City, Dubai BioTechnology \& Research Park, Dubai Outsource Zone, Dubai Internet City, Dubai Environment \& Energy Park, Dubai Maritime City, International Media Production Zone, Dubai Silicon Oasis, Dubai Multi Commodities Centre, Dubai Airport Free Zone, Dubai Flower Centre, Dubai International Financial Centre, Dubai Textile City, Jumeirah Lake Tower, and Dubai International Academic City. Abu Dhabi's free zones are TwoFour54, Masdar City, Abu Dhabi Ports Company, Abu Dhabi Airport Free Zone, and Khalifa Industrial Zone Abu Dhabi (KIZAD). Ras Al Khaimah's (RAK) free zones are RAK Free Trade Zone, RAK Investment Authority, RAK Media City, and RAK Maritime City. Sharjah's free zones are Sharjah Airport International Free Zone and Hamriyah Free Zone. Fujairah's free zones are Fujairah Free Zone, Fujairah Airport Free Zone, and Creative City. Ajman's and Umm Al Quain's (UAQ) free zones are Ajman Free Zone and UAQ's Ahmed Bin Rashed Free Zone.
} 
time period, required mutual consent to renew an agency agreement and allowed either party to file for damages (WTO 2012). However, Federal Law No. 2 of 2010 introduced further amendments to the Commercial Agencies Law, which seem to have partly reverted changes introduced in 2009.

The UAE Cabinet has mandated the Ministry of Economy to implement a National Investment Reform Process that improves the country's investment policy. In November 2011, the Dubai Economic Council (DEC) called for speeding up the ratification of the draft Foreign Investment Law, which offers foreign investors similar rights to those extended to UAE nationals. It also called for clearer regulations governing foreign investment, especially on property rights protection, business disputes settlement and corporate governance. ${ }^{12}$ Resolving insolvency, enforcing contracts and protecting investors are business aspects in which the UAE was ranked the lowest according to the World Bank's (2012) ease of doing business index, compared to its ranking with respect to paying taxes, trading across borders, getting electricity, registering property, dealing with construction permits, and starting a business.

Despite some legal barriers to foreign investment in the UAE, the rapid growth of FDI during most of the period since 2000 reflects an overall confidence of investors in the UAE economy, its business environment and growing competitiveness, both regionally and globally, over time. The World Bank's (2006; 2009; 2010; 2012) Doing Business reports show that the UAE's ease of doing business rank had improved from the 69th position in 2006 to the 46th in 2009 and further to 33rd in 2010; it held the same rank in 2012.

Seeking to improve its competitiveness, the UAE has undertaken reforms that have eased doing business and encouraged investment, both domestic and foreign. Some

\footnotetext{
${ }^{12}$ For a survey of the role that institutions play in attracting FDI and capital flows, see Mina (2011).
} 
of the reforms related to starting a business, ${ }^{13}$ while others have made obtaining credit easier (World Bank 2011). ${ }^{14}$

To strengthen the protection of foreign investors' property rights and encourage foreign investments, the UAE Government had signed a total of 38 bilateral investment treaties (BITs) as of June 1, 2012. ${ }^{15}$ Of the 38 treaties concluded, 14 were signed with OECD countries: Austria, Belgium, Czech Republic, Finland, France, Germany, Italy, Republic of Korea, Luxembourg, Poland, Portugal, Sweden, Switzerland, Turkey, and the United Kingdom. The UAE has also signed 48 double taxation treaties (DTTs), with 46 countries, of which 18 treaties were signed with 17 OECD countries: Austria, Belgium, Canada, Czech Republic, Finland, France, Germany (two treaties), Greece, Ireland, Italy, Republic of Korea, Netherlands, New Zealand, Poland, Portugal, Switzerland, and Turkey.

Aspects of international trade have also been reformed. ${ }^{16}$ Measures have also been taken to ease obtaining construction permits. ${ }^{17}$

The ranking by A.T. Kearney's Foreign Direct Investment Confidence Index, which assesses the impact of economic, political and regulatory changes on FDI intentions based on responses by corporate executives of top companies around the

\footnotetext{
${ }^{13}$ In 2010/2011, the UAE eased the process of starting new businesses by merging the requirements for a) filing company documents with the Department for Economic Development, b) obtaining a trade license and c) registering with the Dubai Chamber of Commerce and Industry (World Bank 2012). In 2008/2009, the UAE had eased the requirements relating to documents needed for business registration, abolished the minimum capital requirement for establishing a business and removed the requirement that proof of deposit of capital be shown for registration (World Bank 2010).

${ }^{14}$ In 2009/2010, Decree no. 8 formally establishing a federal Dubai-based credit bureau (Emcredit) under the supervision of the central bank was issued (World Bank 2012). The aim of this decree is to establish a credit reporting system that provides lenders with the necessary information to support sound lending decisions, and stability to the financial services industry. The decree also regulates the operations of Emcredit and information sharing in the Emirate pursuant to the criteria and instructions stipulated by the Dubai Department of Economic Development (DED) and to the instructions and guidelines issued by the UAE Central Bank. Emcredit began functioning in February 2007 when it started to collect information on the repayment patterns of individual borrowers as well as firms, allowing better supervision of the debt level of banks and borrowers.

${ }^{15}$ On the effect of bilateral investment treaties on FDI in GCC and MENA countries, see Mina $(2009,2010$, and 2012).

${ }^{16}$ In 2009/2010, the UAE launched Dubai Customs' comprehensive new customs system, Mirsal 2, which streamlined document preparation and reduced trading time (World Bank 2011). A year earlier, the UAE increased the capacity at the container terminal, eliminated the terminal handling receipt as a required document and increased trade finance products (World Bank 2010).

${ }^{17}$ The UAE has shortened the time for delivering building permits in 2008/2009 by improving its online system for processing applications (World Bank 2010).
} 
world, ranked the UAE in the $22^{\text {nd }}$ position in 2005 and in the $14^{\text {th }}$ position in $2013 .^{18}$ A.T. Kearney Global Business Policy Council (2013) specifies the strength in the logistics, tourism and hospitality industries, developed infrastructure, strategic location, and tax-free base as favorable factors behind the increase in the FDI flows to the UAE.

It is worth noting that Dubai and Abu Dhabi were the two most preferred destinations for future investments in the Middle East: 28 percent of respondents surveyed by A.T. Kearney for the 2010 ranking indicated that Dubai was their preferred destination, and 18 percent indicated a preference for Abu Dhabi. ${ }^{19}$

\section{THE PATH AHEAD AND FUTURE RESEARCH}

The UAE Government understands the strategic importance of inward FDI in building a sustainable and diversified economy and the current barriers to FDI. In the more recent and farther-future stretching Abu Dhabi Vision 2030, compared to the UAE Vision 2021, the UAE plans to "build a sustainable and diversified, high value-added economy that is well integrated into the global economy and that provides more accessible and higher-value opportunities for all its citizens and residents." 20 The sustainability of the economy is viewed as being founded on economic diversification, which is envisaged in terms of not only broader economic sectors but also of a larger enterprise base. Building such a base rests heavily on encouraging small businesses and entrepreneurship and on strategically promoting FDI in the economy.

UAE policy makers may be tempted to question the benefits of FDI to the UAE economy. UNCTAD's (2012) FDI contribution index for 2009 provides some evidence suggesting that FDI has been beneficial to the UAE in some respects (Table 10). The index indicates that FDI contribution to UAE value-added and wages and salaries was ranked in the first quartile of a group of 79 countries. However, contribution to employment and exports was ranked in the third and fourth quartiles, respectively. Thus the employment generation benefit of FDI may not have been fully realized in the UAE.

\footnotetext{
${ }^{18}$ See A.T. Kearney Global Business Policy Council (2006, 2008, 2010, 2012, and 2013).

${ }^{19}$ See A.T. Kearney Global Business Policy Council (2010). This is the last report in the series that surveyed respondents for their favorite investment destinations in the Middle East.

${ }^{20}$ See Government of Abu Dhabi (2008).
} 
Creating enough job opportunities helps the UAE Government deal with the GCC-wide simmering youth unemployment problem.

\section{[Insert Table 10 here.]}

This outlook can be interlinked with the findings of the FDI literature to generate future research agenda. Future empirical research on the benefits of FDI to UAE economic growth, employment, and technology transfer and knowledge spillovers, at the aggregate, sectorial, and industrial and firm levels is of prime importance. Providing answers to these questions can help the government assess how to maximize the benefits of FDI in the UAE economy. Undertaking research in the UAE can be a very challenging task given the dearth of statistics. 


\section{REFERENCES}

A.T. Kearney Global Business Policy Council (2006), FDI Confidence Index 2005 (Alexandria,Virginia: ATK).

A.T. Kearney Global Business Policy Council (2008), New Concerns in an Uncertain World: The 2007 A.T. Kearney FDI Confidence Index (Vienna, Virginia: ATK).

A.T. Kearney Global Business Policy Council (2010), Investing in a Rebound: The 2010 A.T. Kearney FDI Confidence Index (Vienna,Virginia: ATK).

A.T. Kearney Global Business Policy Council (2012), Cautious Investors Feed a Tentative Recovery: The 2012 A.T. Kearney FDI Confidence Index (Vienna,Virginia: ATK).

A.T. Kearney Global Business Policy Council (2013), Back to Business: Optimism Amid Uncertainty: The 2013 A.T. Kearney FDI Confidence Index (Vienna,Virginia: ATK).

Aitken, B. J. and A. Harrison (1999), 'Do Domestic Firms Benefit from Direct Foreign Investment? Evidence from Venezuela', American Economic Review, 89, 3, 605-18.

Alfaro, L., S. Kalemli-Ozcan and S. Sayek (2009), 'FDI, Productivity and Financial Development', The World Economy, 32, 1, 111-35.

Alfaro, L. and A. Rodriguez-Clare (2004), 'Multinationals and Linkages: Evidence from Latin America', Economia, 4, 2, 113-70.

Blomström, M. and A. Kokko (1998), 'Multinational Corporations and Spillovers', Journal of Economic Surveys, 12, 2, 247-77.

Blömstrom, M. and H. Persson (1983), 'Foreign Investment and Spillover Efficiency in an Underdeveloped Economy: Evidence from the Mexican Manufacturing Industry', World Development, 11, 6, 493-501.

Blömstrom, M. and E. W. Wolff (1994), Multinational Corporations and Productivity Convergence in Mexico, in W. J. Baumol, R. R. Nelson and E. N. Wolff (eds.), 
Convergence of Productivity: Cross-national Studies and Historical Evidence (Oxford: Oxford University Press), 263-84.

Borensztein, E., J. de Gregorio and J. W. Lee (1998), 'How Does Foreign Direct Investment Affect Economic Growth?', Journal of International Economics, 45, 1, 115-35.

Branstetter, L. (2006), 'Is Foreign Direct Investment a Channel of Knowledge Spillovers? Evidence from Japan's FDI in the United States', Journal of International Economics, $68,2,325-44$.

Caves, R. (1974), 'Multinational Firms, Competition and Productivity in the Host Country', Economica, 41, 162, 176-93.

Cipollina, M., G. Giovannetti, F. Pietrovito, and A. F. Pozzolo (2012), 'FDI and Growth: What Cross-country Industry Data Say', The World Economy, 35, 11, 1599-1629.

Globerman, S. (1979), 'Foreign Direct Investment and Spillover Efficiency Benefits in Canadian Manufacturing Industries', Canadian Journal of Economics, 12, 1, 42-56.

Government of Abu Dhabi (2008), The Abu Dhabi Economic Vision 2030 (Abu Dhabi: Abu Dhabi Government).

Haskel, J., S. Pereira and M. J. Slaughter (2006), 'Does Inward Foreign Direct Investment Boost the Productivity of Domestic Firms?', The Review of Economics and Statistics, 89, 3, 482-96.

Keller, W. and S. Yeaple (2009), 'Multinational Enterprises, International Trade, and Productivity Growth: Firm-level Evidence from the United States', The Review of Economics and Statistics, 91, 4, 821-31.

Mina, W. (2008), 'United Arab Emirates Trade Policy Review', The World Economy, $31,11,1443-1453$. 
Mina, W. (2009), 'External Commitment Mechanisms, Institutions, and FDI in GCC countries', Journal of International Financial Markets, Institutions, \& Money, 19, 2, 371-386.

Mina, W. (2010), 'Do Bilateral Investment Treaties Encourage FDI in the GCC Countries?', African Review of Economics and Finance, 2, 1, 1-29.

Mina, W. (2011), 'Institutional Reforms Debate and FDI Flows to MENA Region: Does One “Best” Fit All?’ UNU-WIDER Working Paper No. 2011/50.

Mina, W. M. (2012), 'The Institutional Reforms Debate and FDI Flows to the MENA Region: The "Best” Ensemble", World Development, 40, 9, 1798-1809.

Satyanand, P. N. and P. Raghavendran (2010), 'Outward FDI from India and its Policy Context', Columbia FDI Profiles, Vale Columbia Center on Sustainable International Investment, September 22, 2010.

Sjöholm, F. (1999), 'Productivity Growth in Indonesia: The Role of Regional Characteristics and Direct Foreign Investment', Economic Development and Cultural Change, 47, 3, 559-84.

The Heritage Foundation (2012), 2012 Index of Economic Freedom (Washington, D.C.: The Heritage Foundation).

UNCTAD (1999), World Investment Report 1999: Foreign Direct Investment and the Challenge of Development (Geneva: United Nations).

UNCTAD (2011), World Investment Report 2011: Non-Equity Modes of International Production and Development (Geneva: United Nations).

UNCTAD (2012), World Investment Report 2012: Towards a New Generation of Investment Policies (Geneva: United Nations).

UNCTAD (2013), World Investment Report 2013: Global Value Chains: Investment and Trade for Development (Geneva: United Nations). 
U.S. Government Accountability Office (2008), 'Foreign Investment: Laws and Policies Regulating Foreign Investment in 10 Countries', GAO-08-320, available at http://www.gao.gov/new.items/d08320.pdf.

World Bank (2006), Doing Business 2006: Creating Jobs, Doing (Washington, D.C: World Bank).

World Bank (2009), Doing Business 2009 (Washington, D.C: World Bank).

World Bank (2010), Doing Business 2010: Reforming Through Difficult Times (Washington, D.C: World Bank).

World Bank (2011), Doing Business 2011: Making a Difference for Entrepreneurs (Washington, D.C.: World Bank).

World Bank (2012), Doing Business 2012: Doing Business in a More Transparent World (Washington, D.C: World Bank).

WTO (2006), 'Trade Policy Review: United Arab Emirates', Report by the Secretariat, WT/TPR/S/162, available at http://www.wto.org/english/tratop_e/tpr_e/tp362_e.htm.

WTO (2012), 'Trade Policy Review: United Arab Emirates', Report by the Secretariat, WT/TPR/S/262, available at http://www.wto.org/english/tratop_e/tpr_e/tp362_e.htm. 
TABLE 1

Inward FDI Performance and Potential Index Ranking (2000-2010)

\begin{tabular}{|c|c|c|c|c|c|c|c|}
\hline & 2000 & 2005 & 2006 & 2007 & 2008 & 2009 & 2010 \\
\hline & \multicolumn{7}{|c|}{ FDI Performance Index } \\
\hline UAE & 137 & 19 & 33 & 49 & 54 & 92 & 103 \\
\hline Bahrain & 49 & 20 & 10 & 23 & 30 & 103 & 121 \\
\hline Kuwait & 133 & 131 & 134 & 138 & 137 & 113 & 135 \\
\hline Oman & 123 & 43 & 64 & 35 & 68 & 68 & 54 \\
\hline Qatar & 97 & 35 & 47 & 56 & 79 & 21 & 43 \\
\hline \multirow[t]{2}{*}{ Saudi Arabia } & 131 & 56 & 58 & 54 & 31 & 19 & 29 \\
\hline & \multicolumn{7}{|c|}{ FDI Potential Index } \\
\hline UAE & 22 & 14 & 12 & 7 & 3 & 5 & .. \\
\hline Bahrain & 29 & 28 & 28 & 25 & 22 & 23 & .. \\
\hline Kuwait & 31 & 36 & 35 & 37 & 35 & 37 &.. \\
\hline Oman & 47 & 56 & 53 & 51 & 47 & 39 &.. \\
\hline Qatar & 23 & 12 & 11 & 8 & 6 & 2 &.. \\
\hline Saudi Arabia & 33 & 32 & 29 & 29 & 27 & 29 & .. \\
\hline
\end{tabular}

Source: UNCTAD, World Investment Report 2011: Non-Equity Modes of International Production and Development (Geneva: United Nations), annex tables, web table 28, "Inward FDI Performance and Potential Index rankings, 1990-2010," available at: http://unctad.org/en/Pages/DIAE/World\%20Investment\%20Report/Annex-Tables.aspx 
TABLE 2

Inward FDI Potential 2011 Index

\begin{tabular}{|l|r|r|r|r|r|}
\hline & $\begin{array}{c}\text { Market } \\
\text { attractiveness }\end{array}$ & $\begin{array}{c}\text { Availability of } \\
\text { low-cost labor } \\
\text { and skills }\end{array}$ & $\begin{array}{c}\text { Enabling } \\
\text { infrastructure }\end{array}$ & $\begin{array}{c}\text { Presence of natural } \\
\text { resources }\end{array}$ & $\begin{array}{c}\text { Overall } \\
\text { rank }\end{array}$ \\
\hline UAE & 9 &.. & 28 & 45 & 19 \\
\hline Bahrain & 87 &.. & 32 & 92 & 61 \\
\hline Kuwait & 3 & 84 & 44 & 83 & 60 \\
\hline Oman & 27 & 62 & 61 & 64 & 54 \\
\hline Qatar & 1 & 71 & 45 & 85 & 48 \\
\hline Saudi Arabia & 4 & 14 & 70 & 25 & 15 \\
\hline
\end{tabular}

Source: Annex table of UNCTAD (2012), web table 32A, "Country Rankings by Inward FDI

Potential Index, 2011," available at: http://unctad.org/en/Pages/DIAE/DIAE.aspx.

Notes: See Box 1.3 in UNCTAD (2012) for more information on the economic determinants of the FDI potential index. 
TABLE 3

FDI in the UAE (2000-2012)

\begin{tabular}{|c|c|c|c|c|c|c|c|c|c|c|c|c|c|}
\hline & 2000 & 2001 & 2002 & 2003 & 2004 & 2005 & 2006 & 2007 & 2008 & 2009 & 2010 & 2011 & 2012 \\
\hline & \multicolumn{13}{|c|}{ FDI Stocks (US\$ Billion) } \\
\hline UAE & 1.1 & 2.3 & 2.3 & 6.6 & 16.6 & 27.5 & 40.3 & 54.5 & 68.2 & 72.2 & 77.7 & 85.4 & 95.0 \\
\hline Bahrain & 5.9 & 6.0 & 6.2 & 6.7 & 7.4 & 8.3 & 11.2 & 12.9 & 14.7 & 15.0 & 15.2 & 15.9 & 16.8 \\
\hline Kuwait & 0.6 & 0.4 & 0.4 & 0.4 & 0.4 & 0.6 & 0.8 & 0.9 & 8.7 & 10.2 & 11.9 & 12.4 & 12.8 \\
\hline Oman & 2.6 & 2.6 & 2.7 & 2.7 & 2.8 & 4.4 & 6.0 & 9.3 & 12.3 & 13.7 & 15.0 & 15.7 & 17.2 \\
\hline Qatar & 1.9 & 2.2 & 2.8 & 3.5 & 4.7 & 7.2 & 10.7 & 15.4 & 17.8 & 25.9 & 30.6 & 30.5 & 30.8 \\
\hline \multirow[t]{2}{*}{ Saudi Arabia } & 17.6 & 17.3 & 17.7 & 18.5 & 20.5 & 33.5 & 50.7 & 73.5 & 111.6 & 147.1 & 170.5 & 186.9 & 199.0 \\
\hline & \multicolumn{13}{|c|}{ FDI Stocks (Percent of GDP) } \\
\hline UAE & 1.0 & 2.2 & 2.1 & 5.3 & 11.2 & 15.2 & 18.2 & 21.1 & 21.7 & 27.8 & 27.4 & 25.2 & 26.9 \\
\hline Bahrain & 73.6 & 75.1 & 73.1 & 68.9 & 65.5 & 61.5 & 70.6 & 70.1 & 66.5 & 76.4 & 69.1 & 61.7 & 63.2 \\
\hline Kuwait & 1.6 & 1.2 & 1.2 & 0.8 & 0.7 & 0.8 & 0.8 & 0.8 & 5.9 & 9.7 & 9.5 & 7.7 & 7.4 \\
\hline Oman & 13.2 & 13.3 & 13.5 & 12.7 & 11.5 & 14.2 & 16.2 & 22.2 & 20.3 & 29.3 & 25.3 & 21.6 & 21.8 \\
\hline Qatar & 10.8 & 12.6 & 14.6 & 14.7 & 14.7 & 16.1 & 17.5 & 19.3 & 15.4 & 26.5 & 24.0 & 17.6 & 16.9 \\
\hline \multirow[t]{2}{*}{ Saudi Arabia } & 9.3 & 9.4 & 9.4 & 8.6 & 8.2 & 10.6 & 14.2 & 19.1 & 23.4 & 39.1 & 37.4 & 31.3 & 30.7 \\
\hline & \multicolumn{13}{|c|}{ FDI Flows (US\$ Billion) } \\
\hline UAE & -0.5 & 1.2 & 0.1 & 4.3 & 10.0 & 10.9 & 12.8 & 14.2 & 13.7 & 4.0 & 5.5 & 7.7 & 9.6 \\
\hline Bahrain & 0.4 & 0.1 & 0.2 & 0.5 & 0.9 & 1.0 & 2.9 & 1.8 & 1.8 & 0.3 & 0.2 & 0.8 & 0.9 \\
\hline Kuwait & 0.0 & -0.1 & 0.0 & -0.1 & 0.0 & 0.2 & 0.1 & 0.1 & 0.0 & 1.1 & 0.5 & 0.9 & 1.9 \\
\hline Oman & 0.1 & 0.0 & 0.1 & 0.0 & 0.1 & 1.5 & 1.6 & 3.3 & 3.0 & 1.5 & 1.2 & 0.7 & 1.5 \\
\hline Qatar & 0.3 & 0.3 & 0.6 & 0.6 & 1.2 & 2.5 & 3.5 & 4.7 & 3.8 & 8.1 & 4.7 & -0.1 & 0.3 \\
\hline \multirow[t]{2}{*}{ Saudi Arabia } & 0.2 & 0.5 & 0.5 & 0.8 & 1.9 & 12.1 & 18.3 & 24.3 & 39.5 & 36.5 & 29.2 & 16.3 & 12.2 \\
\hline & \multicolumn{13}{|c|}{ FDI Flows (Percent of GDP) } \\
\hline UAE & -0.5 & 1.1 & 0.1 & 3.4 & 6.8 & 6.0 & 5.8 & 5.5 & 4.4 & 1.5 & 1.9 & 2.3 & 2.7 \\
\hline Bahrain & 4.5 & 1.0 & 2.6 & 5.3 & 7.7 & 7.8 & 18.4 & 9.5 & 8.1 & 1.3 & 0.7 & 3.0 & 3.3 \\
\hline Kuwait & 0.0 & -0.3 & 0.0 & -0.1 & 0.0 & 0.3 & 0.1 & 0.1 & 0.0 & 1.1 & 0.4 & 0.5 & 1.1 \\
\hline
\end{tabular}




\begin{tabular}{|l|c|c|c|c|c|c|c|c|c|c|c|c|c|}
\hline & 2000 & 2001 & 2002 & 2003 & 2004 & 2005 & 2006 & 2007 & 2008 & 2009 & 2010 & 2011 & 2012 \\
\hline Oman & 0.4 & 0.0 & 0.6 & 0.1 & 0.4 & 5.0 & 4.3 & 8.0 & 4.9 & 3.2 & 2.1 & 1.0 & 1.9 \\
\hline Qatar & 1.4 & 1.7 & 3.2 & 2.7 & 3.8 & 5.6 & 5.7 & 5.9 & 3.3 & 8.3 & 3.7 & -0.1 & 0.2 \\
\hline Saudi Arabia & 0.1 & 0.3 & 0.2 & 0.4 & 0.8 & 3.8 & 5.1 & 6.3 & 8.3 & 9.7 & 6.4 & 2.7 & 1.9 \\
\hline
\end{tabular}

Source: UNCTAD's FDI/TNC database, available at: www.unctad.org/fdistatistics 
TABLE 4

Sectorial Distribution of Inward FDI Stock (2005-2009)

(Percent of Total)

\begin{tabular}{|l|r|r|r|r|r|}
\hline & 2005 & 2006 & 2007 & 2008 & 2009 \\
\hline & \multicolumn{5}{|c|}{ Share (percent) } \\
\hline Agriculture and fisheries & 0.3 & 0.1 & 0.2 & 0.2 & 0.2 \\
\hline Extraction industries & 2.6 & 2.5 & 3.1 & 3.1 & 2.6 \\
\hline Manufacturing industries & 10.0 & 9.7 & 8.2 & 8.2 & 9.7 \\
\hline Electricity and water & 2.1 & 2.1 & 4.8 & 4.8 & 2.1 \\
\hline Construction and building & $\mathbf{2 4 . 2}$ & $\mathbf{2 2 . 0}$ & $\mathbf{1 9 . 3}$ & $\mathbf{1 9 . 3}$ & $\mathbf{2 1 . 9}$ \\
\hline Wholesale and retail trade & $\mathbf{1 4 . 4}$ & 13.8 & 10.3 & 10.3 & 13.7 \\
\hline Hotels and restaurants & 2.1 & 1.7 & 1.0 & 1.0 & 1.8 \\
\hline Transportation and communications & 4.5 & 7.2 & 4.1 & 4.1 & 7.3 \\
\hline Financial institutions & $\mathbf{2 5 . 8}$ & $\mathbf{2 2 . 9}$ & $\mathbf{2 0 . 7}$ & $\mathbf{2 0 . 7}$ & $\mathbf{2 2 . 9}$ \\
\hline Real estate & 13.2 & $\mathbf{1 7 . 2}$ & $\mathbf{2 7 . 9}$ & $\mathbf{2 7 . 9}$ & $\mathbf{1 7 . 2}$ \\
\hline Other & 0.6 & 0.7 & 0.3 & 0.3 & 0.7 \\
\hline \multicolumn{7}{|c|}{ (US\$ billion) } \\
\hline Total (US\$ billion) & 16.7 & 20.2 & 34.6 & 41.8 & 52.9 \\
\hline Source: Wor
\end{tabular}

Source: World Trade Organization, “Trade Policy Review: United Arab Emirates", Report by the Secretariat, WT/TPR/S/262, February 21, 2012, table I.3, available at www.wto.org/english/tratop_e/tp362_e.htm. Note: Bold fonts highlight the highest three shares. 
TABLE 5

Geographical Distribution of Inward FDI Flows from OECD Economies (2001-2011)

\begin{tabular}{|c|c|c|c|c|c|c|c|c|c|c|c|}
\hline \multicolumn{12}{|c|}{ (US\$ Million) } \\
\hline & 2001 & 2002 & 2003 & 2004 & 2005 & 2006 & 2007 & 2008 & 2009 & 2010 & 2011 \\
\hline Australia & .. & .. & -78 & 15 & .. & 226 & .. & 952 & 445 & .. & .. \\
\hline Austria & .. & .. & .. & .. & .. & .. & .. & .. & .. & .. & .. \\
\hline Belgium & .. & .. & .. & .. & -99 & 64 & 475 & -3699 & -514 & 3364 & 975 \\
\hline Canada & .. & .. & .. & .. & .. & .. & .. & .. & .. & .. & .. \\
\hline Chile & .. & .. & .. & .. & .. & 503 & 145 & -101 & 1935 & 11764 & 574 \\
\hline $\begin{array}{l}\text { Czech } \\
\text { Republic }\end{array}$ & .. & .. & -508 & 1126 & 307 & -1128 & -3 & 38 & -21 & .. & -3 \\
\hline Denmark & .. & .. & .. & .. & 422 & 1466 & 2181 & 2414 & -5958 & 372 & 181 \\
\hline Estonia & .. & .. & .. & .. & .. & 2 & 4 & 3 & .. & .. & 2 \\
\hline Finland & .. & 94 & 305 & -62 & 51 & -251 & -41 & 211 & 98 & 9 & -587 \\
\hline France & 394 & 1093 & -96 & 808 & 1243 & 2874 & 2396 & 11681 & 667 & 2556 & 28 \\
\hline Germany & 313 & 151 & 689 & 447 & -385 & 3263 & 2409 & 5512 & -611 & 1868 & 4136 \\
\hline Greece & .. & .. & .. & 96 & 29 & -15 & -1 & 122 & 138 & -14 & -8 \\
\hline Hungary & .. & .. & 0 & .. & 3 & 13 & 11 & 1 & -5 & 8 & 4 \\
\hline Iceland & .. & .. & .. & .. & .. & .. & 0 & 1 & 0 & 37 & -42 \\
\hline Ireland & .. & .. & .. & .. & .. & .. & .. & .. & .. & .. & .. \\
\hline Israel & .. & .. & .. & .. & .. & .. & .. & .. & .. & .. & .. \\
\hline Italy & .. & .. & .. & 5 & 99 & 226 & 78 & 659 & 5891 & 16188 & 800 \\
\hline Japan & .. & .. & .. & 28 & 191 & -567 & 586 & 1915 & 1389 & -5618 & 2104 \\
\hline Korea & .. & .. & .. & 82 & .. & 96 & 675 & 309 & 793 & 524 & 343 \\
\hline Luxembourg & .. & -34 & -104 & 245 & 9 & 35 & 483 & 184674 & -446 & 2058 & 338 \\
\hline Mexico & .. & .. & .. & .. & .. & .. & .. & .. & .. & .. & .. \\
\hline Netherlands & -519 & 1659 & 1604 & -758 & -597 & -1594 & 2683 &.. & .. &.. & .. \\
\hline New Zealand & .. & .. & .. & .. & .. & .. &.. & .. & -98 & -7 & -75 \\
\hline Norway &.. &.. &.. & .. &.. & .. & .. & 117 & 1215 & 822 & .. \\
\hline Poland & .. & .. & .. & .. & .. & .. & .. & .. & .. & 46 & 267 \\
\hline Portugal & .. & .. & .. & .. & .. & .. & .. & .. & .. & .. & .. \\
\hline $\begin{array}{l}\text { Slovak } \\
\text { Republic }\end{array}$ &.. & .. &.. &.. &.. &.. &.. &.. &.. & .. & .. \\
\hline
\end{tabular}




\begin{tabular}{|l|r|r|r|r|r|r|r|r|r|r|r|}
\hline & 2001 & 2002 & 2003 & 2004 & 2005 & 2006 & 2007 & 2008 & 2009 & 2010 & 2011 \\
\hline Slovenia &.. &.. &.. &.. &.. & 5 & 54 & 0 & 69 & 39 & -61 \\
\hline Spain &.. &.. &.. &.. &.. &.. &.. &.. &.. & 715 & 1365 \\
\hline Sweden & -75 & -88 & -42 & -23 & -23 & -5 &.. & 1138 & -166 & 604 & 316 \\
\hline Switzerland & 327 & -337 & -163 & 28 & -38 & 1422 & -178 & 73523 & -7444 & -16851 & 41662 \\
\hline Turkey &.. &.. &.. &.. & 1 & 1 & 13 & 30 & 17 & 10 & 4 \\
\hline UK &.. & 4305 & -3087 & -1905 & 7144 & 438 & 7144 & 3699 & 19554 & 3553 & -8638 \\
\hline US &.. & 400 & 186 & 13450 & -64 & 13220 & 255 & 286 & 10220 & 279 & 11040 \\
\hline
\end{tabular}

Source: The author, based on individual OECD countries' reporting on outward FDI flows, obtained from OECD, StatExtracts, available at http://stats.oecd.org/. Data extracted on 27 Nov 2013 22:49 UTC (GMT) from OECD.Stat

Note: '..' indicates that data are not available. 
TABLE 6

Number and Value of Cross-Border M\&As and Greenfield Projects (2003-2012)

\begin{tabular}{|l|c|c|c|c|c|c|c|c|c|c|c|c|}
\hline & 2003 & 2004 & 2005 & 2006 & 2007 & 2008 & 2009 & 2010 & 2011 & 2012 \\
\hline & \multicolumn{8}{|c|}{ Number } \\
\hline Greenfield FDI projects & 150 & 158 & 231 & 305 & 311 & 522 & 414 & 323 & 373 & 328 \\
\hline Cross-border M\&As & 7 & 7 & 12 & 13 & 18 & 27 & 13 & 20 & 31 & 28 \\
\hline & \multicolumn{8}{|c|}{ Value in US\$ Billion } \\
\hline Greenfield FDI projects & 8.95 & 3.61 & 12.21 & 15.33 & 17.74 & 36.22 & 15.07 & 12.87 & 11.62 & 12.05 \\
\hline Cross-border M\&As & 0.02 & 0.01 & 0.06 & 0.05 & 0.86 & 1.22 & 0.30 & 0.76 & 0.56 & 0.22 \\
\hline
\end{tabular}

Source: Annex tables 9, 11, 19 and 22 of UNCTAD (2013) available at http://unctad.org/en/Pages/DIAE/World\%20Investment\%20Report/Annex$\underline{\text { Tables.aspx }}$ 
TABLE 7

Main Greenfield Projects (2008-2010)

(by inward investing firm)

\begin{tabular}{|c|c|c|c|c|}
\hline Date & Investing company & $\begin{array}{l}\text { Home } \\
\text { economy }\end{array}$ & Industry & $\begin{array}{c}\text { Estimated/announced } \\
\text { investment value (US\$ } \\
\text { million) }\end{array}$ \\
\hline 2010 & $\begin{array}{l}\text { National Real Estate } \\
\text { Company }\end{array}$ & Kuwait & Construction & $1,000.0$ \\
\hline 2010 & CapitaLand & Singapore & Construction & 484.1 \\
\hline 2010 & Giorgio Armani & Italy & Construction & 484.1 \\
\hline 2010 & Realty Capital & $\begin{array}{l}\text { United } \\
\text { States }\end{array}$ & Construction & 484.1 \\
\hline 2010 & $\begin{array}{l}\text { Aegean Marine Petroleum } \\
\text { Network }\end{array}$ & Greece & $\begin{array}{l}\text { Transportation, } \\
\text { communications and } \\
\text { utilities }\end{array}$ & 472.4 \\
\hline 2010 & Royal Dutch Shell Plc & Netherlands & $\begin{array}{l}\text { Transportation, } \\
\text { communications and } \\
\text { utilities }\end{array}$ & 472.4 \\
\hline 2010 & Metalloinvest & Russia & Manufacturing & 320.0 \\
\hline 2010 & Abengoa & Spain & Construction & 281.7 \\
\hline 2010 & Polo Group & India & Construction & 217.9 \\
\hline 2010 & Accor & France & Construction & 201.5 \\
\hline 2010 & Marriott International & $\begin{array}{l}\text { United } \\
\text { States }\end{array}$ & Construction & 201.5 \\
\hline 2010 & TUI & Germany & Construction & 201.5 \\
\hline 2010 & TUI & Germany & Construction & 201.5 \\
\hline 2010 & Whitbread & $\begin{array}{l}\text { United } \\
\text { Kingdom }\end{array}$ & Construction & 201.5 \\
\hline 2009 & Hydrogen Energy & $\begin{array}{l}\text { United } \\
\text { Kingdom }\end{array}$ & $\begin{array}{l}\text { Transportation, } \\
\text { communications and } \\
\text { utilities }\end{array}$ & $2,000.0$ \\
\hline 2009 & $\begin{array}{l}\text { National Ranges } \\
\text { Company (Mayadeen) }\end{array}$ & Kuwait & Construction & 952.8 \\
\hline 2009 & $\begin{array}{l}\text { Crown Dilmun } \\
\text { Development Company }\end{array}$ & Bahrain & Construction & 500.0 \\
\hline 2009 & Smartlink & Jordan & $\begin{array}{l}\text { Transportation, } \\
\text { communications and } \\
\text { utilities }\end{array}$ & 500.0 \\
\hline 2009 & Hiranandani Developers & India & Construction & 479.7 \\
\hline 2009 & Sika & Switzerland & Manufacturing & 460.8 \\
\hline 2009 & EMC Corporation & $\begin{array}{l}\text { United } \\
\text { States }\end{array}$ & $\begin{array}{l}\text { Transportation, } \\
\text { communications and } \\
\text { utilities }\end{array}$ & 400.0 \\
\hline 2009 & $\begin{array}{l}\text { Millenium Energy } \\
\text { Industries (MEI) }\end{array}$ & Jordan & $\begin{array}{l}\text { Transportation } \\
\text { communications and } \\
\text { utilities }\end{array}$ & 243.1 \\
\hline
\end{tabular}




\begin{tabular}{|c|c|c|c|c|}
\hline Date & Investing company & $\begin{array}{c}\text { Home } \\
\text { economy }\end{array}$ & Industry & $\begin{array}{c}\text { Estimated/announced } \\
\text { investment value (US\$ } \\
\text { million) }\end{array}$ \\
\hline 2009 & Fashion Hotels & Austria & Construction & 206.9 \\
\hline 2009 & Hyatt International & $\begin{array}{l}\text { United } \\
\text { States }\end{array}$ & Construction & 206.9 \\
\hline 2009 & $\begin{array}{l}\text { The Grand Midwest } \\
\text { Group }\end{array}$ & Ireland & Construction & 206.9 \\
\hline 2009 & $\begin{array}{l}\text { The Grand Midwest } \\
\text { Group }\end{array}$ & Ireland & Construction & 206.9 \\
\hline 2009 & Rezidor Hotel Group & Belgium & Construction & 206.9 \\
\hline 2009 & $\begin{array}{l}\text { Shangri-La Hotels and } \\
\text { Resorts }\end{array}$ & $\begin{array}{l}\text { Hong Kong } \\
\text { (China) }\end{array}$ & Construction & 206.9 \\
\hline 2009 & $\begin{array}{l}\text { Starwood Hotels \& } \\
\text { Resorts }\end{array}$ & $\begin{array}{l}\text { United } \\
\text { States }\end{array}$ & Construction & 206.9 \\
\hline 2009 & Whitbread & $\begin{array}{l}\text { United } \\
\text { Kingdom }\end{array}$ & Construction & 206.9 \\
\hline 2009 & Whitbread & $\begin{array}{l}\text { United } \\
\text { Kingdom }\end{array}$ & Construction & 206.9 \\
\hline 2008 & DSECO & $\begin{array}{l}\text { Korea, Rep. } \\
\text { of }\end{array}$ & Construction & $4,002.0$ \\
\hline 2008 & Sunland Group & Australia & Construction & $2,200.0$ \\
\hline 2008 & IT Holding & Italy & Construction & $1,200.0$ \\
\hline 2008 & Giga Group & Pakistan & Construction & 735.0 \\
\hline 2008 & $\begin{array}{l}\text { Merlin Entertainments } \\
\text { Group }\end{array}$ & $\begin{array}{l}\text { United } \\
\text { Kingdom }\end{array}$ & Construction & 641.6 \\
\hline 2008 & $\begin{array}{l}\text { Anheuser-Busch } \\
\text { Companies Inc }\end{array}$ & $\begin{array}{l}\text { United } \\
\text { States }\end{array}$ & Construction & 641.6 \\
\hline 2008 & Hit Entertainment & $\begin{array}{l}\text { United } \\
\text { Kingdom }\end{array}$ & Construction & 641.6 \\
\hline 2008 & Six Flags & $\begin{array}{l}\text { United } \\
\text { States }\end{array}$ & Construction & 641.6 \\
\hline 2008 & Viacom & $\begin{array}{l}\text { United } \\
\text { States }\end{array}$ & Construction & 641.6 \\
\hline 2008 & Yash Raj Films & India & Construction & 641.6 \\
\hline
\end{tabular}

Source: The author, based on fDi Intelligence, a service from the Financial Times Ltd. 
TABLE 8

Top M\&A Deals (2008-2010)

\begin{tabular}{|c|c|c|c|c|c|c|}
\hline Year & $\begin{array}{l}\text { Acquiring } \\
\text { company }\end{array}$ & $\begin{array}{l}\text { Home } \\
\text { economy }\end{array}$ & Target company & Target industry & $\begin{array}{l}\text { Shares } \\
\text { acquired } \\
\text { (Percent) }\end{array}$ & $\begin{array}{l}\text { Estimated/announced } \\
\text { transaction value (US\$ } \\
\text { million) }\end{array}$ \\
\hline 2010 & $\begin{array}{l}\text { Undisclosed } \\
\text { acquirer }\end{array}$ & Unknown & $\begin{array}{l}\text { The Ritz Carlton } \\
\text { Hotel-Dubai }\end{array}$ & Hotels and motels & 100 & 299.5 \\
\hline 2010 & Afren PLC & $\begin{array}{l}\text { United } \\
\text { Kingdom }\end{array}$ & $\begin{array}{l}\text { Black Marlin Energy } \\
\text { Holding Ltd }\end{array}$ & Investors & 100 & 106.3 \\
\hline 2010 & $\begin{array}{l}\text { Oaktree Capital } \\
\text { Management } \\
\text { LP }\end{array}$ & $\begin{array}{l}\text { United } \\
\text { States }\end{array}$ & $\begin{array}{l}\text { Gulmar Offshore } \\
\text { Middle East }\end{array}$ & $\begin{array}{l}\text { Crude petroleum and } \\
\text { natural gas }\end{array}$ & .. & 100 \\
\hline 2010 & $\begin{array}{l}\text { Undisclosed } \\
\text { Acquirer }\end{array}$ & Unknown & $\begin{array}{l}\text { Ensco Offshore Co- } \\
\text { Ensco } 51\end{array}$ & $\begin{array}{l}\text { Crude petroleum and } \\
\text { natural gas }\end{array}$ & 100 & 95 \\
\hline 2010 & $\begin{array}{l}\text { Zee } \\
\text { Entertainment } \\
\text { Enterprises }\end{array}$ & India & $\begin{array}{l}\text { Taj Television Ltd } \\
\text { Mauritius }\end{array}$ & $\begin{array}{l}\text { Television } \\
\text { broadcasting stations }\end{array}$ & 45 & 44.1 \\
\hline 2010 & $\begin{array}{l}\text { Renaissance } \\
\text { Services SAOG }\end{array}$ & Oman & $\begin{array}{l}\text { Al Wasita Emirates } \\
\text { for Services and } \\
\text { catering LLC }\end{array}$ & $\begin{array}{l}\text { Eating and drinking } \\
\text { places }\end{array}$ & 100 & 15.2 \\
\hline 2010 & $\begin{array}{l}\text { Warba } \\
\text { Insurance Co } \\
\text { KSC }\end{array}$ & Kuwait & Al Ghazal Logistics & $\begin{array}{l}\text { Air transportation, } \\
\text { nonscheduled }\end{array}$ & 5 & 11 \\
\hline 2010 & $\begin{array}{l}\text { Dice Holdings } \\
\text { Inc }\end{array}$ & $\begin{array}{l}\text { United } \\
\text { States }\end{array}$ & $\begin{array}{l}\text { WWW.com-Online } \\
\text { Related Bus }\end{array}$ & $\begin{array}{l}\text { Employment } \\
\text { agencies }\end{array}$ & 100 & 9 \\
\hline 2010 & $\begin{array}{l}\text { Undisclosed } \\
\text { Acquirer }\end{array}$ & Unknown & $\begin{array}{l}\text { Dubai Pipe Factory } \\
\text { Co LLC }\end{array}$ & Steel pipe and tubes & 22.5 & 8.2 \\
\hline 2010 & $\begin{array}{l}\text { HCL } \\
\text { Infosystems Ltd }\end{array}$ & India & NTS Group & $\begin{array}{l}\text { Business consulting } \\
\text { services }\end{array}$ & 60 & 6.5 \\
\hline 2009 & $\begin{array}{l}\text { Khazanah } \\
\text { Nasional } \\
\text { Berhad }\end{array}$ & Malaysia & Fajr Capital Ltd & Investors & 25 & 150 \\
\hline 2009 & Tradelabs PLC & $\begin{array}{l}\text { United } \\
\text { Kingdom }\end{array}$ & $\begin{array}{l}\text { Real Value } \\
\text { Consultancy FZE }\end{array}$ & $\begin{array}{l}\text { Security and } \\
\text { commodity brokers } \\
\text { and services }\end{array}$ & 100 & 130 \\
\hline 2009 & $\begin{array}{l}\text { Securities } \\
\text { Group Co } \\
\text { KSCC }\end{array}$ & Kuwait & RAK Real Estate Ltd & $\begin{array}{l}\text { Real estate } \\
\text { investment trusts }\end{array}$ & 9.9 & 91.8 \\
\hline 2009 & $\begin{array}{l}\text { Huntsworth } \\
\text { PLC }\end{array}$ & $\begin{array}{l}\text { United } \\
\text { Kingdom }\end{array}$ & $\begin{array}{l}\text { Momentum } \\
\text { International Ltd }\end{array}$ & Advertising & 100 & 12 \\
\hline 2009 & $\begin{array}{l}\text { Zylog Systems } \\
\text { Ltd }\end{array}$ & India & Ducont FZ-LLC & $\begin{array}{l}\text { Computer integrated } \\
\text { systems design }\end{array}$ & 100 & 7.5 \\
\hline 2009 & $\begin{array}{l}\text { RDS(Technical) } \\
\text { Ltd }\end{array}$ & Jersey & TTERS & $\begin{array}{l}\text { Equipment rental and } \\
\text { leasing }\end{array}$ & 66.7 & 0.3 \\
\hline 2009 & $\begin{array}{l}\text { Natural Bio } \\
\text { Resources } \\
\text { Berhad }\end{array}$ & Malaysia & $\begin{array}{l}\text { Synergy Distribution } \\
\text { FZC }\end{array}$ & Durable goods & 51 & 0 \\
\hline 2009 & $\begin{array}{l}\text { Jabbar Internet } \\
\text { Group }\end{array}$ & Jordan & Ikoo & $\begin{array}{l}\text { Computer related } \\
\text { services }\end{array}$ & 100 & .. \\
\hline 2009 & $\begin{array}{l}\text { Toll Holdings } \\
\text { Ltd }\end{array}$ & Australia & $\begin{array}{l}\text { Logistics } \\
\text { Distribution System }\end{array}$ & $\begin{array}{l}\text { Arrangement of } \\
\text { transportation of } \\
\text { freight and cargo }\end{array}$ & 100 & .. \\
\hline 2009 & Averda & Lebanon & Al Ghadeer Waste & Air and water & 100 & .. \\
\hline
\end{tabular}




\begin{tabular}{|c|c|c|c|c|c|c|}
\hline Year & $\begin{array}{l}\text { Acquiring } \\
\text { company }\end{array}$ & $\begin{array}{c}\text { Home } \\
\text { economy }\end{array}$ & Target company & Target industry & $\begin{array}{l}\text { Shares } \\
\text { acquired } \\
\text { (Percent) }\end{array}$ & $\begin{array}{c}\text { Estimated/announced } \\
\text { transaction value (US\$ } \\
\text { million) }\end{array}$ \\
\hline & & & Collections & $\begin{array}{l}\text { resource and solid } \\
\text { waste management }\end{array}$ & & \\
\hline 2009 & Mawarid Group & $\begin{array}{l}\text { Saudi } \\
\text { Arabia }\end{array}$ & Showtime Arabia & $\begin{array}{l}\text { Cable and other pay } \\
\text { television services }\end{array}$ & 100 & .. \\
\hline 2009 & $\begin{array}{l}\text { SS8 Networks } \\
\text { Inc }\end{array}$ & $\begin{array}{l}\text { United } \\
\text { States }\end{array}$ & OCI Mobile & $\begin{array}{l}\text { Prepackaged } \\
\text { Software }\end{array}$ & 100 & .. \\
\hline 2009 & QFIB & Qatar & ENPI Group & Plastics products & 71.3 & .. \\
\hline 2009 & $\begin{array}{l}\text { International } \\
\text { Assets Holding }\end{array}$ & $\begin{array}{l}\text { United } \\
\text { States }\end{array}$ & $\begin{array}{l}\text { INTL Commodities } \\
\text { DMCC }\end{array}$ & $\begin{array}{l}\text { Commodity contracts } \\
\text { brokers and dealers }\end{array}$ & 50 & .. \\
\hline 2009 & $\begin{array}{l}\text { Undisclosed } \\
\text { Acquirer }\end{array}$ & Unknown & OGEC Group & Engineering services & 50 & .. \\
\hline 2009 & Eaton Corp & $\begin{array}{l}\text { United } \\
\text { States }\end{array}$ & $\begin{array}{l}\text { SEG Middle East } \\
\text { Power }\end{array}$ & $\begin{array}{l}\text { Switchgear, } \\
\text { switchboard } \\
\text { apparatus }\end{array}$ & 49 & .. \\
\hline 2009 & $\begin{array}{l}\text { Franklin } \\
\text { Resources } \\
\text { Incorporated }\end{array}$ & $\begin{array}{l}\text { United } \\
\text { States }\end{array}$ & Algebra Capital Ltd & Investment advice & 15 & .. \\
\hline 2009 & $\begin{array}{l}\text { Shore Capital } \\
\text { Group PLC }\end{array}$ & $\begin{array}{l}\text { United } \\
\text { Kingdom }\end{array}$ & $\begin{array}{l}\text { Full Circle } \\
\text { Investments FZC }\end{array}$ & Investment advice & 5 & .. \\
\hline 2008 & $\begin{array}{l}\text { Saudi Telecom } \\
\text { Co }\end{array}$ & $\begin{array}{l}\text { Saudi } \\
\text { Arabia }\end{array}$ & Oger Telecom Ltd & $\begin{array}{l}\text { Telephone } \\
\text { communications, } \\
\text { except } \\
\text { radiotelephone }\end{array}$ & 35 & $2,850.0$ \\
\hline 2008 & $\begin{array}{l}\text { Commercial } \\
\text { Bank of Qatar } \\
\text { QSC }\end{array}$ & Qatar & United Arab Bank & Banks & 40 & 599.6 \\
\hline 2008 & QNB & Qatar & $\begin{array}{l}\text { Commercial Bank } \\
\text { International }\end{array}$ & Banks & 23.8 & 302.4 \\
\hline 2008 & $\begin{array}{l}\text { Eitzen Maritime } \\
\text { Services ASA }\end{array}$ & Norway & $\begin{array}{l}\text { Seven Seas } \\
\text { Shipchandlers LLC }\end{array}$ & $\begin{array}{l}\text { Repair shops and } \\
\text { related services }\end{array}$ & 100 & 112.4 \\
\hline 2008 & $\begin{array}{l}\text { Thomas Cook } \\
\text { UK Ltd }\end{array}$ & $\begin{array}{l}\text { United } \\
\text { Kingdom }\end{array}$ & TC Overseas Ltd & Travel agencies & 100 & 70.5 \\
\hline 2008 & Diamant Co Ltd & $\begin{array}{l}\text { Korea } \\
\text { (Rep. of) }\end{array}$ & $\begin{array}{l}\text { SMI Hyundai Corp } \\
\text { Ltd UAE }\end{array}$ & $\begin{array}{l}\text { Residential } \\
\text { construction }\end{array}$ & 100 & 57.8 \\
\hline 2008 & $\begin{array}{l}\text { Al-Safat } \\
\text { Investment Co } \\
\text { KSCC }\end{array}$ & Kuwait & $\begin{array}{l}\text { Orimix Concrete } \\
\text { Products LLC }\end{array}$ & $\begin{array}{l}\text { Ready-mixed } \\
\text { concrete }\end{array}$ & 60 & 49.8 \\
\hline 2008 & $\begin{array}{l}\text { Undisclosed } \\
\text { acquirer }\end{array}$ & Unknown & $\begin{array}{l}\text { United Printing \& } \\
\text { Publishing }\end{array}$ & $\begin{array}{l}\text { Book publishing, or } \\
\text { publishing and } \\
\text { printing }\end{array}$ & 40 & 31.3 \\
\hline 2008 & $\begin{array}{l}\text { Hyder } \\
\text { Consulting PLC }\end{array}$ & $\begin{array}{l}\text { United } \\
\text { Kingdom }\end{array}$ & $\begin{array}{l}\text { Holford \& } \\
\text { Associates }\end{array}$ & $\begin{array}{l}\text { Business consulting } \\
\text { services }\end{array}$ & 100 & 30.5 \\
\hline 2008 & $\begin{array}{l}\text { Tarsus Group } \\
\text { PLC }\end{array}$ & $\begin{array}{l}\text { United } \\
\text { Kingdom }\end{array}$ & $\begin{array}{l}\text { Fairs \& } \\
\text { Exhibitions(1992)Ltd }\end{array}$ & $\begin{array}{l}\text { Amusement and } \\
\text { recreation services }\end{array}$ & 100 & 22.2 \\
\hline
\end{tabular}

Source: The author, based on Thomson Reuters, Thomson ONE Banker.

Note: '..' indicates that data are not available. 
TABLE 9

Fortune 500 U.S. Companies with Affiliates in UAE (2011)

\begin{tabular}{|l|l|l|l|}
\hline Abbott Laboratories & Eli Lilly \& Company & Honeywell International & Occidental Petroleum \\
\hline Boeing Company & ExxonMobil & HP & Oshkosh \\
\hline Booz Allen Hamilton & Fedex & IBM & Pepsi \\
\hline CH2M HILL & Fluor & J.P. Morgan Chase & Pfizer \\
\hline Chevron & General Dynamics & Kellogg & Starbucks \\
\hline Coca-Cola & General Electric & Lockheed Martin & $3 \mathrm{M}$ \\
\hline ConocoPhillips & General Mills & Mastercard & Tyson Foods \\
\hline Dow Chemical & General Motors & McDonald's & UPS \\
\hline DuPont & Goldman Sachs & Motorola & Visa \\
\hline & & NCR & Western Union \\
\hline & & Northrop Grumman & \\
\hline
\end{tabular}

Source: The author, based on information from the U.S.-UAE Business Council website, available at http://usuaebusiness.org, and the American Business Council of Dubai and the Northern Emirates website, available at http://www.abcdubai.com; and the Fortune Magazine's ranking of Fortune 500 companies for 2011, available at http://money.cnn.com/magazines/fortune/fortune500/2011/index.html. 
TABLE 10

FDI Contribution Index, rankings and indicator quartiles,2009 (Quartile rankings for shares of each indicator in economy totals)

\begin{tabular}{|l|r|r|r|l|l|l|l|}
\hline & $\begin{array}{l}\text { Value } \\
\text { added }\end{array}$ & Employment & Exports & Tax Revenue & $\begin{array}{l}\text { Wages } \\
\text { and } \\
\text { Salaries }\end{array}$ & $\begin{array}{l}\text { R\&D } \\
\text { Exp. }\end{array}$ & $\begin{array}{l}\text { Capital } \\
\text { Exp. }\end{array}$ \\
\hline UAE & 1 & 3 & 4 &.. & 1 &.. & 4 \\
\hline $\begin{array}{l}\text { Saudi } \\
\text { Arabia }\end{array}$ & 4 & 4 & 4 &.. & 4 &.. & 4 \\
\hline
\end{tabular}

Source: Annex table I.10 of UNCTAD (2012) - World Investment Report 2012: Towards a New Generation of Investment Policies - available at

http://unctad.org/en/PublicationsLibrary/wir2012 embargoed en.pdf. 